\title{
The Popularity of Integration Models, 1980-1985
}

\author{
JAMES D. FOSTER, DEBRA A. HORN, and STEVE WATSON \\ George Fox College \\ Newberg, Oregon
}

Farnsworth's five integration models were used to categorize integration articles published in the Joumal of Psychology and Theology between 1980 and 1985. In addition, the graduate education of article authors was examined to determine if educational background influenced integration approach. Of the 177 articles reviewed, 52 reported research and 76 were considered integration articles. Results of the review indicate that one integration model accounts for nearly $/ 3 / 3$ of the integration work presented in $J P T$ during this period and that differences in educational preparation do not produce preferences for particular integration approaches.

Since its inception over a decade ago, the Journal of Psychology and Theology (JPT) has stimulated widespread interest in the integration of psychology and theology by serving as an outlet and focal point for discussion. As a result of this expanding interest in integration some authors have felt the need to describe, label, and organize integration styles. The resulting classification systems are seemingly designed to clarify the relationship between psychology and Christianity and give direction to integration efforts. The theorists engaged in these efforts have produced a wide variety of integration models that vary in approach and in the number of categories hypothesized.

Carter (1977) has suggested four integration approaches; "psychology against religion," "psychology of religion," "psychology parallels religion" and "psychology integrates religion." Collins (1981) identified six different approaches to integration. These included "the denial approach," "the railroad track

Requests for reprints should be sent to James D. Foster, PhD, Department of Psychology, George Fox College, Newberg, Oregon 97132. approach," "the levels of analysis approach," and so forth. In 1982, Kirk Farnsworth identified two broad categories of integration: manipulation and correlation. Manipulation models attempt to subsume psychological or theological facts under each other or relabel the other's concepts. Correlational models focus on the agreement or complementarity of the psychological and theological facts. Farnsworth identified three manipulative integration models (Credibility, Convertibility, Conformability) and two correlational integration models (Compatibility and Complementarity).

Each of these classification systems has its strengths and weaknesses and each reflects to a certain degree the value system of the authors. For example, Carter and Narramore (1979) evaluated each of the four models that they proposed, concluding that the "Against" model has no advantages, the "Of" model is more helpful but still has serious limitations, and the "Parallels" model has several basic strengths but also suffers from serious limitations. Only the "Integrates" model is judged completely sufficient. Similarly, Farnsworth (1982) discussed five approaches to integration and evaluated each as to its strengths and 
weaknesses. In this discussion it becomes clear that some models are to be preferred over others. Farnsworth then concluded his article with a discussion of "Embodied Integration," described as "the culmination of the integration process."

While the preferences of integration modelers are of interest, it would be of equal interest to know which models are preferred by the psychologists and theologians who are actually engaged in the integration process. Farnsworth (1982), in describing the creation of his models, wrote:

Rather than deductively fitting what appears in the literature into prior categories, as some have done (e.g., Carter \& Narramore, 1979), it seems more appropriate to observe what categories are revealed in the literature and then inductively incorporate them. This is the manner in which the ... models described here were developed." (p. 315)

It would seem equally appropriate to then go further and empirically support the existence of the models as suggested and to use the models to demonstrate the nature and scope of each type of integration. Discussions of theoretical models of integration are of endless interest but at some point it is necessary to $\mathrm{mix}$ the practice of integration in the trenches with theory.

The purpose of this review, then, was not to join the theoretical arguments over proper approaches to integration, but rather to assess the popularity of integration approaches. While authors of taxonomies will cite examples for each of their integration models, there has been no systematic effort to determine the most often used models. Feedback on how integration is being approached is important for two reasons. First, it bridges the gap between integration theory and integration reality and takes the discussion from what should and shouldn't be done to what is being done. This is vital at some point since theory may have no relation to practice. Second, if through model building theorists intend to monitor or even influence the integration process, it is necessary to eventually establish a baseline from which to judge trends and changes in integration approaches.

After examining the available integration taxonomies, Farnsworth's (1982) five-model approach was selected as the basis of our survey. Farnsworth's models were selected partly because of his claim to an inductive basis for his model system. If the models were indeed based on his observations of what is being published in the literature then the model should lend itself well to the classification task. In addition, Farnsworth clearly specified the criteria for determining which approach researchers are using in their integrative writings.

\section{Farnsworth's Models}

Farnsworth (1982) proposed five distinct integration models:

1. Credibility Model: This is a filter model where the Bible is used to filter secular ideas. In this model psychological facts which conflict with the teaching of Scripture are to be rejected. These conflicting psychological facts are to be screened by scriptural teaching regardless of empirical support.

2. Convertibility Model: This is a filter model where theological facts are filtered through secular disciplines, in this case psychology. It is essentially the reverse of the Credibility Model. Theological facts inconsistent with the teaching of psychology are to be rejected.

3. Conformability Model: This model emphasizes the reinterpretation of secular facts. In this model the discipline being integrated is seen through the Christian world view. While it is similar to the Credibility Model in that it does involve filtering psychology through theology, it does not simply reject inconsistencies. Rather, psychological inconsistencies are reworked to make them theologically acceptable.

4. Compatibility Model: This approach correlates similar secular and theological facts with both sets of facts given equal weight. The emphasis is on identifying those psychological and theological facts that are consistent. Since the focus is on consistency, reworking of either sets of facts is not necessary.

5. Complementarity Model: The discipline is subsumed under the more general category 


\section{J.D. FOSTER, D.A. HORN, and S. WATSON}

of theology. Theology and secular disciplines are seen as noncompetitive and answering different kinds of questions. The more general category of theology is used to give psychology a broader perspective. Psychological facts are not altered in this approach and psychological facts need not be lined up against theological facts since they are at different levels.

Our early work with this classification system suggested that Farnsworth's (1982) "Conformability Model" actually contained two subcategories. Farnsworth labeled the Conformability Model as the "Worldview approach" and described this kind of integration as incorporating the discipline of the person within their beliefs. In practice, however, it appears that the integrating person can either use their psychological world view to rework psychology or use their Christian world view to rework theological concepts. Because of this the authors felt it would be of interest to distinguish between the two world view approaches. Conformability (A) refers to those individuals who rework psychological concepts from the Christian perspective and Conformability (B) refers to those individuals who rework theological issues from a psychological perspective.

\section{The Review}

Six years of the Journal of Psychology and Theology were surveyed by three raters. In order for an article to be assigned to an integration model two of the three reviewers must have independently assigned the article to that category. The 6 years surveyed included 177 articles. Since the articles contained in JPT include not only integration articles, but also research, comment, response, and so forth, two additional categories were added for those articles that could not be classified according to one of the integration types. One of the categories contained articles we classified as research and the other was a miscellaneous category that contained commentary, articles advocating a particular integration approach but not actually integrating, and articles for which the reviewers could not reach the classification criteria. Of the 177 articles reviewed, 5 could not meet the classification criteria. Some articles in $J P T$ are preceded by the label "research." An article's assignment to our "research" category required the same $2 / 3$ agreement and was independent of the presence or absence of the research label.

\section{Journal Content}

Our review resulted in $43 \%$ of the articles being assigned to the miscellaneous category. Our review also indicates that there has been an increase in the amount of research being published in the Journal. Goldsmith (1983) reported a $15-20 \%$ rate of research articles during the first 10 years of the Journal while by our count, which overlapped the Goldsmith count, the last 6 years have produced a $29.3 \%$ rate. A look at the percentage of research articles by year indicates growth since 1980 . Of the 1980 articles we reviewed, $12 \%$ were classified as research; in subsequent years the percentages were $28 \%, 27 \%, 38 \%, 35 \%$, and $43 \%$. The percentage of articles not classified as research or integration decreased during the same period with $50 \%, 25 \%, 33 \%, 32 \%, 4 \%$ and $10 \%$. The percentage of integration articles during this same 6-year period remained relatively stable with $38 \%, 47 \%$, $40 \%, 30 \%, 61 \%$, and $47 \%$ respectively.

\section{Integration Categories}

Of the $\mathbf{7 6}$ articles classified as integration, $36 \%$ were judged to be using the Conformability (A) approach, while Conformability (B) accounted for $26 \%$ and Compatibility $30 \%$ (see Table 1). The Credibility Model accounted for $8 \%$ of integration approaches. None of the articles reviewed were judged as using the Convertability or Complementarity approaches. Farnsworth (1982) indicated that his categories of integration were inductively generated and based on a review of the literature. Our classification, however, finds no article fitting two of Farnsworth's categories-Convertibility and Complementarity. This discrepancy may be due to several factors. First, the literature he surveyed would be the years before the publication of his 


\section{INTEGRATION MODELS, 1980-1985}

Table 1

Summary Table of Integration Articles ${ }^{1}$

\begin{tabular}{|c|c|}
\hline Credibility Model & Timpe (1983) \\
\hline Carter $(1980)^{2}$ & Vitz \& Gartner (1984a) \\
\hline Crabb (1981) & Thomas (1984) \\
\hline Lewis \& Lewis (1982) & Vitz \& Gartner (1984b) \\
\hline Powlison (1984) & Shepperson \& Henslin (1984) \\
\hline Clark, D.K. (1985) & Shepperson (1984) \\
\hline Liaboe $(1985)$ & Jeske (1984) \\
\hline Conformability (A) & Clark, D.L. (1984) \\
\hline Hartz (1980) & Compatibility \\
\hline Farnsworth (1980) & Talley (1980) \\
\hline Meyer (1980) & Propst (1980) \\
\hline Strong (1980) & Boghosian (1980) \\
\hline Kotesky (1980) & Marvin (1980) \\
\hline Ratcliff (1980) & Moy (1980) \\
\hline McKeown (1981) & Shepperson (1981) \\
\hline Martin \& Martin (1981) & Spidell \& Liberman (1981) \\
\hline Collins \& Tornquist (1981) & Beck $(1981)$ \\
\hline Vanderploeg (1981b) & Guy (1982) \\
\hline Kopas (1981) & Grauf-Grounds (1982) \\
\hline Vanderploeg (1981a) & Sanders \& Malony (1982) \\
\hline Danco (1982) & Walsh (1983) \\
\hline Lacocque (1982) & Deschenes \& Shepperson (1983) \\
\hline Vande Kemp (1982) & Boghosian (1983) \\
\hline Schweigerdt (1982) & McMinn \& McMinn (1983) \\
\hline Duek (1983) & McMinn (1984) \\
\hline Benner (1983) & $\operatorname{Cox}(1984)$ \\
\hline Stehouwer \& Stehouwer (1983) & Liesch \& Finley (1984) \\
\hline Nelson \& Wilson (1984) & Ashbrook (1984) \\
\hline Jones (1984) & Pingleton (1985) \\
\hline Barber (1984) & Foster \& Moran (1985) \\
\hline White, S.A. (1984) & Sabom (1985) \\
\hline Bishop (1985) & Lee (1985) \\
\hline Narramore (1985) & Research \\
\hline Liaboe (1985) & Mellor \& Andre (1980) \\
\hline Roberts (1985) & Virkler (1980) \\
\hline Conformability (B) & Rytting \& Christensen (1980) \\
\hline Hall (1980) & Goring (1980) \\
\hline Morgan, Levandowski, \& Rogers (1981) & Cameron \& Ross (1981) \\
\hline Young (1981) & Daniel \& Rogers (1981) \\
\hline Rogers (1981) & Gilbert (1981) \\
\hline Deschenes \& Rogers (1981) & Abramczyk (1981) \\
\hline Malony (1981) & Linebaugh \& Devivo (1981) \\
\hline Cohen (1982) & Hsieh (1981) \\
\hline O'Donnell (1982) & Basset et al. (1981) \\
\hline Peake, Stehouwer, \& Stehouwer (1982) & Henning (1981) \\
\hline Heinrichs (1982) & Galligan-Stierle \& Rapp (1981) \\
\hline White, F.J. (1983) & Westendorp (1982) \\
\hline Pike (1983) & Furnham (1982) \\
\hline
\end{tabular}

'No articles were classified as using either the Convertability or Complementarity model.

${ }^{2}$ Author names are in order of Journal appearance. 
Table 1 (Continued)

Summary Table of Integration Articles

\author{
Atwater \& Smith (1982) \\ Schumm, Bollman, \& Jurich (1982). \\ Morgan (1982) \\ Kauffmann \& Zook (1982) \\ Rumberger \& Rogers (1982) \\ Dougherty \& Worthington (1982) \\ Goldsmith (1983) \\ Ellison \& Mattila (1983) \\ Ritzema \& Young (1983) \\ Margolis \& Elifson (1983) \\ Cureton (1983) \\ Britt (1983) \\ Dillon (1983) \\ Taylor \& Malony (1983) \\ Wickstrom \& Fleck (1983) \\ Gish (1983) \\ Ferguson et al. (1983) \\ Worthington \& Scott (1983) \\ Ellison (1983)
}

article in 1982. We began our review in 1980. Including the normal publication lag there is little overlap in the literature we considered. Second, our integration review is limited to $J P T$ and Farnsworth may have been considering a wider body of literature such as The Journal for the Scientific Study of Religion, The Journal of the American Scientific Affiliation, and book publications. It is possible that each of these other sources may have a preference for the approaches less represented in $J P T$. Third, it is also possible we did not fully understand Farnsworth's criteria for distinguishing one integration approach from another. While we consider it unlikely that we misconstrued the criteria for the convertibility approach, since it is the reverse of the Credibility Model and we did find articles fitting this approach, we are less certain about the Complementarity category.

In Farnsworth's (1982) original conception of the integration approaches, the Conformability category was one unified model. Combining our A and B subdivisions of this category produces an integration percentage of $62 \%$. It is interesting that our review places nearly $2 / 3$ of the integration articles published

\author{
Pechue \& Edwards (1984) \\ Ekhardt \& Goldsmith (1984) \\ Larzelere (1984) \\ Warner \& Carter (1984) \\ Goldsmith \& Ekhardt (1984) \\ Flagg (1984) \\ Gass (1984) \\ Wright (1984) \\ Townsend \& Wichern (1984) \\ Worthington \& Gascoyne (1985) \\ Pecnik \& Epperson (1985) \\ Ruppert \& Rogers (1985) \\ Finney \& Malony (1985a) \\ Watson, Hood, Morris, \& Hall (1985) \\ Blackbird \& Wright (1985) \\ Finney \& Malony (1985b) \\ Clouse (1985) \\ Aycock \& Noaker (1985)
}

in $J P T$ into the Conformability categories. Since so many integrationists are using this approach, psychologists and theologians interested in integration need to look carefully at this model.

Farnsworth (1982) describes the Conformability model as emphasizing relabeling, reinterpreting, and reconstructing. In our expanded version of his model, psychological facts are reworked to fit the integrator's theological world view or theological facts are reworked to fit the integrator's psychological world view. Other theorists have used different labels for this same basic approach. For example, the Conformability (B) model appears to correspond roughly to Carter and Narramore's (1979) "Of" model which they describe as a "cookie cutter" approach through which "the theories of psychology are pressed onto the dough of Scripture. The dough that fits within the cutter is retained while whatever falls outside is rejected" (p. 89). Lawrence Crabb (1977) describes an approach he labels as "nothing but-ery" (p. 40) which is also similar to Farnsworth's Conformability model. Collins (1981), in describing Crabb's approach, writes, "Religion 


\section{INTEGRATION MODELS, 1980-1985}

is 'nothing but' a psychologically classifiable concept, or psychology is 'nothing but' a restatement of concepts that are already in the Bible" (p. 31). Interestingly, Collins also writes that this approach "appears to be common in psychology" (p. 31).

Our review supports Collins' (1981) perception that this approach is common and suggests that it is actually dominant. Since $62 \%$ of the integration taking place can be categorized as Conformability it appears that integration largely amounts to efforts by those interested in psychology to create a unified world view through active reconstruction and relabeling. Some of these integrationists are using their psychological world view to reconstruct theology while others are using their theological world view to reconstruct psychology. According to our review these integrationists divide roughly in half, with $57 \%$ reinterpreting psychological facts from the perspective of theological facts (e.g., Barber, 1984; Benner, 1983; Danco, 1982) and $43 \%$ reinterpreting theological facts from the perspective of psychological facts (e.g., Jeske, 1984; White, F.J., 1983; Young, 1981). According to the integration theorists noted above, the principle danger of this approach is that elements of psychology and/ or elements of theology may be left out of the newly reinterpreted, reconstructed, integrated world view.

The two filter models account for very little of the actual integration published in $J P T$. The Credibility version of filtering is described by Farnsworth (1982) as giving theology "functional control over psychology" (p. 315). Psychological facts that conflict with theological facts are to be rejected regardless of their theoretical or empirical support. For example Crabb (1977) recommends that we use Scripture as the "infallible, inspired, inerrant" test of psychology (p. 49). Similarly, Collins (1981) writes, "I am firmly committed to the position that the Bible must be our ultimate source of truth and the conclusions from psychology must be tested against the teachings of Scripture" (p. 129). Farnsworth, however, argues against this "theological imperialism":
It is contradictory to claim that theological, supposedly God-made (sacred) facts are superior to or automatically "truer" than psychological, merely man-made (secular) facts, regardless of the topic and evidence to the contrary, and then claim with conviction that all truth is God's truth. (p. 315)

While there are many advocates of the filter approach, only $8 \%$ of the integration articles published in $J P T$ were judged to fit this category (e.g., Clark, D.K., 1985; Crabb, 1981; Lewis \& Lewis, 1982). Apparently psychologists are unwilling to use theology as a filter. It is interesting to note, though, that those publishing in $J P T$ are even less likely to filter theology through psychology. The Convertibility Model is described by Farnsworth as having the goal of filtering "the theological through the psychological, to remove theological cloaks-of-ignorance" (p. 315). We could find no integration attempts that used psychology as a filter, although other publication outlets may be a better source for this type of integration. A comparison with other publication outlets or conference presentations might help complete the picture of integration approaches.

The remaining $30 \%$ of the integration articles were judged to fit the Compatibility approach to integration (e.g., Ashbrook, 1984; McMinn \& McMinn, 1983; Propst, 1980; Shepperson, 1981). Farnsworth (1982) described this approach as relating psychological and theological facts that seem to be saying the same thing and giving both kinds of facts equal footing. This approach is described as the "railroad track approach" by Collins (1981) and the "Parallels" model by Carter and Narramore (1979). According to these authors there are positive aspects to this approach but the danger with this model lies in its potential for superficiality. Psychological and theological facts may appear on the surface to be saying the same thing, but a more comprehensive understanding of each may prove that there are significant differences between the secular and Christian concepts identified as parallel. It would be interesting to collect the 23 articles identified as taking this approach and examine them for potential underlying conflict or consonance. The writers 


\section{J.D. FOSTER, D.A. HORN, and S. WATSON}

of these articles believed that they were dealing with psychological concepts that were scripturally and theologically sound. If there proves to be no grounds for the suspected superficiality, then Christian psychology may have generated a body of literature that could serve as the core for a true integrated psychology.

\section{Professional Training}

In addition to integration approaches, the researchers reviewed the professional training of the authors themselves. It seemed possible that certain integration approaches would appeal to authors with particular training. For example, someone with a completely secular background may prefer the Conformability (B) approach while someone with training from a religious institution would prefer Conformability (A) or perhaps Credibility.

Author information, including degrees and from where obtained, is included at the end of each article in JPT. While some authors reported undergraduate degrees, it was decided to focus only on graduate degrees since most undergraduate programs emphasize a liberal arts education. Three categories were used in the review: (a) did the authors have advanced secular degrees only, (b) degrees from Christian programs only, or (c) degrees from both Christian and secular programs. In situations where there were multiple authors the degrees for all authors were evaluated and only one category assignment made. Our assumption was that all authors contributed to the article and that the secular or religious training of one contributing author would, at least potentially, be reflected in the article.

Three of the six Credibility articles were written by authors with only secular training, two with Christian training, and one with both. Of the Conformability (A) articles, $63 \%$ were written by secularly trained scholars, $30 \%$ by authors with only Christian training and $7 \%$ by those with both kinds of training. Of the Conformability (B) articles, $65 \%$ fit the secular training category, $20 \%$ the Christian, and $15 \%$ the both category. In the Compatibility category, $43 \%$ were produced by secularly trained people, $35 \%$ by those with
Christian training and $22 \%$ by people with both kinds of graduate training. In the research category, $60 \%$ was produced by authors with secular training only, $17 \%$ by authors with backgrounds in Christian programs and 23\% with backgrounds in both. Chi-square analysis indicated no significant relationship between type of training and integration model used $\chi^{2}(8, N=128)=6.694, p=.57$.

It is important to note that the overwhelming number of graduate programs offering advanced degrees in psychology are in secular institutions. It is not surprising then that $83 \%$ of the research being done is conducted by those with at least some secular training. It is interesting, though, that authors with degrees from Christian programs only are better represented in the integration approaches than in the research. This difference could be a result of many factors including a lack of sufficient research training in Christian programs, the fact that most Christian programs produce practitioners, or that research opportunities are scarcer for those working in Christian institutions.

Certain authors have suggested that part of the failure of integrationists is the lack of theological training for integrationists. For example, Carter and Narramore (1979) cite the "superficial understanding of Christianity" (p. 32) as one barrier to integration. Similarly, Collins (1981) recommends that integration should be done by "trained psychologists" who are also "discerning theologians" (p. 135) and Crabb (1977) believes that integrationists should have "at least as much time spent in the study of the Bible as in the study of psychology" (p. 50). While it is not possible from our review to determine whether those from Christian programs do better integration, it does appear that theological training does not necessarily produce a one right approach to integration. Those with graduate training from Christian institutions were distributed among the integration approaches in the same manner as those without the Christian training.

\section{Summary and Conclusions}

Integration theorists have proposed several overlapping systems for classifying integration 


\section{INTEGRATION MODELS, 1980-1985}

work. The number of models depends on the particular system but varies from four approaches to six. In practice, however, two basic approaches to integration dominate in the articles published in JPT. Most of the JPT authors are either attempting to reconstruct psychology or theology using their theological or psychological world view or they are busy lining up secular and theological facts that appear, at least superficially, to be consistent. Few integrationists are willing to filter psychology through theology and none of those publishing in JPT were willing to filter theology through psychology. Although integration theorists have stressed the importance of biblical and theological training for integrationists, the presence or absence of graduate training from a Christian program does not produce consistent preferences for one integration approach over others. However, those with training from Christian programs are not as well represented in research publication as they are in integration writings.

While this review is limited to 6 years of publication in $J P T$, it appears that those involved in integration have demonstrated a clear preference in approaching integration. Since the existing models of integration seem sufficient for classifying and describing the integration work, it seems time to shift away from theorizing about integration models. A fruitful new direction might be to examine the growing body of integration literature for theologically and psychologically consistent facts or themes that can serve as the basis for building a true Christian psychology.

\section{References}

Abramczyk, L.W. (1981). The counseling function of pastors: A study of practice and preparation. Journal of Psychology and Theology, 9, 257-265.

Ashbrook, J.B. (1984). Juxtaposing the brain and belief. Journal of Psychology and Theology, 12, 198-207.

Atwater, J.M., \& Smith, D. (1982). Christian therapists' utilizaton of bibliotherapeutic resources. Journal of Psychology and Theology, 10, 230-235.

Aycock, D.W., \& Noaker, S. (1985). A comparison of the self-esteem levels in evangelical Christian and general populations. Journal of Psychology and Theology, 13, 199-209.
Barber, C.J.(1984). Marriage, divorce and remarriage: A review of the relevant religious literature. Journal of Psychology and Theology, 12, 170-177.

Basset, R.L., Sadler, R.D., Kobischen, E.E., Skiff, D.M., Merrill, I.J., Atwater, B.J., \& Livermore, P.W. (1981). The shepherd scale: Separating the sheep from the goats. Journal of Psychology and Theology, 9, 335-351.

Beck, J.R. (1981). Treatment of spiritual doubt among obsessing Evangelicals. Journal of Psychology and Theology, 9, 224-231.

Benner, D.G. (1983). The incarnation as a metaphor for psychotherapy.Journal of Psychology and Theology, 11, 287-294.

Bishop, L.C. (1985). Healing in the koinonia: Therapeutic dynamics of church community. Journal of Psychology and Theology, 13, 12-20.

Blackbird, T., \& Wright, P.H. (1985). Pastors' friendships, part 1: Project overview and an exploration of the pedestal effect. Journal of Psychology and Theology, 13, 274-283.

Boghosian, J. (1980). Theology recapitulates ontogeny: Reality testing as an analogy in relating to God. Journal of Psychology and Theology, 8, 122-128.

Boghosian, J. (1983). The biblical basis for strategic approaches in pastoral counseling. Journal of Psychology and Theology, 11, 99-107.

Britt, W.G., III. (1983). Pretraining variables in the prediction of missionary success overseas. Journal of Psychology and Theology, 11, 203-212.

Cameron, P..\& Ross. K.P. (1981). Social psychological aspects of the Judeo-Christian stance toward homosexuality. Journal of Psychology and Theology, 9, 4057.

Carter, J.D. (1977). Secular and sacred models of psychology and religion. Journal of Psychology and Theology, 5, 197-208.

Carter, J.D. (1980). Towards a biblical model of counseling. Journal of Psychology and Theology, 8, 4552.

Carter, J.D., \& Narramore, B. (1979). The integration of psychology and theology. Grand Rapids: Zondervan.

Clark. D.K. (1985). Philosophical reflections on selfworth and self-love. Journal of Psychology and Theology, 13, 3-11.

Clark, D.L. (1984). An implicit theory of personality, illness and cure found in the writings of Neo-Pentecostal faith teachers. Journal of Psychology and Theology, 12, 279-285.

Clouse, B. (1985). Moral reasoning and Christian faith. Journal of Psychology and Theology, 13, 190-198.

Cohen, E.J. (1982). Induced Christian neurosis: An examination of pragmatic paradoxes and the Christian faith. Journal of Psychology and Theology, 10, 5-12. 


\section{J.D. FOSTER, D.A. HORN, and S. WATSON}

Collins, G.R. (1981). Psychology and theology: Prospects for integration. Nashville: Abingdon.

Collins, G.R., \& Tournquist, L.M. (1981). Training Christian people helpers: Observations on counselor education. Journal of Psychology and Theology, 9, 6980.

Cox, W.F. (1984). Spiritual egocentrism: A perspective on spiritual maturity. Journal of Psychology and Theology, $12,40-44$.

Crabb, L.J. (1977). Effective biblical counseling. Grand Rapids: Zondervan.

Crabb, L.J. (1981). Biblical authority and Christian psychology. Journal of Psychology and Theology, 9, 305-311.

Cureton, C.B. (1983). Missionary fit: A criterion-related model. Journal of Psychology and Theology, 11, 196202.

Danco, J.C. (1982). The ethics of fee practices: An analysis of presuppositions and accountability.Journal of Psychology and Theology, 10, 13-21.

Daniel, S., \& Rogers, M.L. (1981). Burn-out and the pastorate: A critical review with implications for pastors. Journal of Psychology and Theology, 9, 232-249.

Deschenes, P., \& Rogers, M.L. (1981). A systems view of Jesus as change agent. Journal of Psychology and Theology, 9, 128-135.

Deschenes, P., \& Shepperson, V.L. (1983). The ethics of paradox. Journal of Psychology and Theology, 11, 9298.

Dillon, D.E. (1983). Personality characteristics of evangelical missionaries as measured by the MMPI. Journal of Psychology and Theology, 11, 213-217.

Dougherty, S.G., \& Worthington. E.L., Jr. (1982). Preferences of conservative and moderate Christians for four Christian counselors' treatment plans. Journal of Psychology and Theology, 10, 346-354.

Duek, A. (1983). American psychology in cross-cultural context. Journal of Psychology and Theology, 11, 172180.

Ekhardt, B.N., \& Goldsmith, W.M. (1984). Personality factors of men and women pastoral candidates, part 1 : Motivational profiles. Journal of Psychology and Theology, 12, 109-118.

Ellison, C.W. (1983). Spiritual well-being: Conceptualization and measurement. Journal of Psychology and Theology, 11, 330-340.

Ellison, C.W., \& Mattila, W.S. (1983). The needs of evangelical Christian leaders in the United States. Journal of Psychology and Theology, 11, 28-35.

Farnsworth, K.E. (1980). Christian psychotherapy and the culture of professionalism. Journal of Psychology and Theology, 8, 115-121.
Farnsworth, K.E. (1982). The 'conduct of integration. Journal of Psychology and Theology, 10, 308-319.

Ferguson, L.N., Kliewer, D., Lindquist, S.E., Williams, D.E., \& Heinrich, R.P. (1983). Candidate selection criteria: A survey. Journal of Psychology and Theology, 11, 243-251.

Finney, J.R., \& Malony, H.N., Jr. (1985a). Empirical studies of Christian prayer: A review of the literature. Journal of Psychology and Theology, 13, 104-115.

Finney, J.R., \& Malony, H.N., Jr. (1985b). An empirical study of contemplative prayer as an adjunct to psychotherapy. Journal of Psychology and Theology, 13, 284290.

Flagg, K. (1984). Psychological androgyny and selfesteem in clergywomen. Journal of Psychology and Theology, 12, 222-229.

Foster, J.D., \& Moran, G.T. (1985). Piaget and parables: The convergence of secular and scriptural views of learning. Journal of Psychology and Theology, 13, 97103.

Furnham, A.F. (1982). Locus of control and theological beliefs. Journal of Psychology and Theology, 19, 130136.

Galligan-Stierle, M., \& Rapp, H.M. (1981). A course in religious community and its effects on self-concept. Journal of Psychology and Theology, 9, 359-363.

Gass. C.S. (1984). Orthodox Christian values related to psychotherapy and mental health. Journal of Psychology and Theology, 12, 230-237.

Gilbert, M.G. (1981). The decision by Assemblies of God pastors to counsel or refer. Journal of Psychology and Theology, 9, 250-256.

Gish, D.J. (1983). Sources of missionary stress. Journal of Psychology and Theology, 11, 236-242.

Goldsmith, W.M. (1983). Remembrances of data past: A review of the journal's empirical research, 1973-1982. Journal of Psychology and Theology, 11, 11-19.

Goldsmith, W.M., \& Ekhardt, B.N. (1984). Personality factors of men and women pastoral candidates, part 2: Sex-role preferences. Journal of Psychology and Theology, 12, $211-221$.

Goring, P. (1980). A personality comparison of evangelical seminarians, Catholic nuns, and university graduates in a Colombian setting. Journal of Psychology and Theology, 8, 323-327.

Grauf-Grounds, C. (1982). Language as change agent: Metaphor in the work of Jay Haley and in the parables of Jesus. Journal of Psychology and Theology, 10, 212220.

Guy, J.D. (1982). Affirming diversity in the task of integration: A response to "Biblical authority and Christian psychology." Journal of Psychology and Theology, 10, 35-39. 


\section{INTEGRATION MODELS, 1980-1985}

Hall, G.C.N. (1980). An integration of science and theology in a Piagetian epistemology. Journal of Psychology and Theology, 8, 293-302.

Hartz, G.W. (1980). The Denial of Death: Foundations for an integration of psychological and theological views of personality. Journal of Psychology and Theology, 8, 53-60.

Heinrichs, D.J. (1982). Our father which art in heaven: Parataxic distortions in the image of God. Journal of Psychology and Theology, 10, 120-129.

Henning, G. (1981). An analysis of correlates of perceived positive and negative prayer outcomes. Journal of Psychology and Theology, 9, 352-358.

Hsieh, T.Y. (1981). Cognitive styles and word versus spirit orientations among Christians. Journal of Psychology and Theology, 9, 175-182.

Jeske, J.O. (1984). Varieties of approaches to psychotherapy: Options for the Christian therapist. Journal of Psychology and Theology,12, 260-269.

Jones, S.L. (1984). Assertiveness training in Christian perspective. Journal of Psychology and Theology, 12, 91-99.

Kauffmann, D.K., \& Zook, A. (1982). Reply to Mellor and Andre's "Religious group value patterns and motive orientations": Data and comment. Journal of Psychology and Theology, 10, 256-258.

Kopas, J. (1981). Jung and Assagioli in religious perspective. Journal of Psychology and Theology, 9, 216-223.

Kotesky, R.L. (1980). Toward the development of a Christian psychology: Emotion. Journal of Psychology and Theology, 9, 303-313.

Lacocque, P.-E. (1982). Desacralizing life and its mystery: The Jonah complex revisited. Journal of Psychology and Theology, 10, 113-119.

Larzelere, R.E. (1984). Dyadic trust and generalized trust of secular-versus Christian-college students. Journal of Psychology and Theology, 12, 119-124.

Lee, C. (1985). The good-enough family. Journal of Psychology and Theology, 13, 182-189.

Lewis, K.N., \& Lewis, D.A. (1982). A biblical analysis of values clarification. Journal of Psychology and Theology, 10, 40-46.

Liaboe, G.P. (1985). The place of wife battring in considering divorce. Journal of Psychology and Theology, 13, 129-138.

Liaboe, G.P., \& Guy, J.D. (1985). Masochism and the distortion of servanthood. Journal of Psychology and Theology, 13, 255-262.

Liesch, B.W., \& Finley, T.J. (1984). The biblical concept of creativity: Scope, definition, criteria. Journal of Psychology and Theology, 12, 188-197.
Linebaugh, D.E., \& Devivo, P. (1981). The growing emphasis on training pastor-counselors in protestant seminaries. Journal of Psychology and Theology, 9, 266268.

Malony, H.N. (1981). Religious experiencing: A phenomenological analysis of a unique behavioral event. Journal of Psychology and Theology, 9, 326-334.

Margolis, R.D., \& Elifson, K.W. (1983). Validation of a typology of religious experience and its relationship to the psychotic experience. Journal of Psychology and Theology, 11, 135-141.

Martin, E.D., \& Martin, R.K. (1981). Developmental and ethical issues in homosexuality: Pastoral implications. Journal of Psychology and Theology, 9, 58-68.

Marvin, M.L. (1980). Social modeling: A psychologicaltheological perspective. Journal of Psychology and Theology, 8, 211-221.

McKeown, B. (1981). Myth and its denial in a secular age: The case of behaviorist psychology. Journal of Psychology and Theology, 9, 12-20.

McMinn, M.R. (1984). Religious values and clienttherapist matching in psychotherapy. Journal of Psychology and Theology, 12, 24-33.

McMinn, M.R., \& McMinn, G.N. (1983). Complete yet inadequate: The role of learned helplessness and selfattribution from the writings of Paul. Journal of Psychology and Theology, 11, 303-310.

Mellor, S., \& Andre, J. (1980). Religious group value patterns and motive orientations. Journal of Psychology and Theology, 8, 129-139.

Meyer, C. (1980). Pastoral counseling as sacramental act. Joumal of Psychology and Theology, 8, 147-151.

Morgan, D.D. (1982). Needs assessment in churches: $A$ Christian community's need for professional counseling services. Journal of Psychology and Theology, 10, 242250 .

Morgan, D.D., Levandowski, D., \& Rogers, M. (1981). The apostle Paul: Problem formation and problem resolution from a systems perspective. Joumal of Psychology and Theology, 9, 136-143.

Moy, A.C. (1980). Assertive behavior in a New Testament perspective. Journal of Psychology and Theology, 8, 288-292.

Narramore, B. (1985). The concept of responsibility in psychopathology and psychotherapy. Journal of Psychology and Theology, 13, 91-96.

Nelson, A.A., \& Wilson, W.P. (1984). The ethics of sharing religious faith in psychotherapy. Joumal of Psychology and Theology, 12, 15-23.

O'Donnell, J.G. (1982). The influence of Freud's hermeneutic of suspicion on the writings of Juan Segundo. Journal of Psychology and Theology, 10, 28-34. 


\section{J.D. FOSTER D.A. HORN, and S. WATSON}

Peake, T.W., Stehouwer, R.S., \& Stehouwer, N.D. (1982). Schematic portrayal: Parents' cognitive styles and children's developmental health. Journal of Psychology and Theology, 10, 47-54.

Pecheur, D.R., \& Edwards, K.J. (1984). A comparison of secular and religious versions of cognitive therapy with depressed Christian college students. Journal of Psychology and Theology, 12, 45-54.

Pecnik, J.A., \& Epperson, D.L. (1985). A factor analysis and further validation of the shepherd scale. Journal of Psychology and Theology, 13, 42-49.

Pike, P.L. (1983). Assimilation and accommodation applied to vernacular scriptures-in-use. Journal of Psychology and Theology, 11, 189-195.

Pingleton, J.P. (1985). Group counseling in the church: An integrative theoretical and practical analysis. Journal of Psychology and Theology, 13, 21-28.

Powlison, D.A. (1984). Which presuppositions: Secular psychology and the categories of biblical thought. Journal of Psychology and Theology, 12, 270-278.

Propst, R.L. (1980). A comparison of the cognitive restructuring psychotherapy paradigm and several spiritual approaches to mental health. Journal of Psychology and Theology, 8, 107-114.

Ratcliff, D. (1980). Toward a Christian perspective of developmental disability. Journal of Psychology and Theology, 8, 328-335.

Ritzema, R.J., \& Young, C. (1983). Causal schemata and the attribution of supernatural causality. Journal of Psychology and Theology, 11, 36-43.

Roberts, R.C. (1985). Carl Rogers and the Christian virtues. Journal of Psychology and Theology, 13, 263273.

Rogers, M.L. (1981). The call of Abram: A systems theory analysis. Journal of Psychology and Theology, 9, 111-127.

Rumberger, D.J., \& Rogers, M.L. (1982). Pastoral openness to interaction with a private Christian counseling service. Journal of Psychology and Theology, 10, 337 345.

Ruppert, P.P., \& Rogers, M.L. (1985). Needs assessment in the development of a clergy consultation service: A key informant approach. Journal of Psychology and Theology, $13,50-60$.

Rytting, M., \& Christensen, H.T. (1980). The effect of religious orthodoxy: A statistical analogy. Journal of Psychology and Theology, 8, 314-322.

Sabom, W.S. (1985). The gnostic world of anorexia nervosa. Journal of Psychology and Theology, 13, 243254.

Sanders, R.K., \& Malony, H.N. (1982). A theological and psychological rationale for assertiveness training. Journal of Psychology and Theology, 10, 251-255.
Schumm, W.R., Bollman, S.R., \& Jurich, A.P. (1982). The "marital conventionalization" argument: Implications for the study of religiosity and marital satisfaction. Journal of Psychology and Theology, 10, 236-241.

Schweigerdt, B. (1982). The gnostic influence on psychology: Effects of the common heresy. Journal of Psychology and Theology, 10, 221-229.

Shepperson, V.L. (1981). Paradox, parables, and change: One approach to Christian hypnotherapy. Journal of Psychology and Theology, 9, 3-11.

Shepperson, V.L. (1984). Jacob's journey: From narcissism toward wholeness. Journal of Psychology and Theology, 12, 178-187.

Shepperson, V.L., \& Henslin, E.R. (1984). Hypnosis and metaphor in Christian context: History, abuse, and use. Journal of Psychology and Theology, 12, 100-108.

Spidell, S., \& Liberman, D. (1981). Moral development and the forgiveness of sin. Journal of Psychology and Theology, 9, 159-163.

Stehouwer, N.D., \& Stehouwer, R.S. (1983). A Christian approach to authority and discipline in the family: Theological-theoretical issues and research findings. Journal of Psychology and Theology, 11, 341-349.

Strong, S.R. (1980). Christian counseling with homosexuals. Journal of Psychology and Theology, 8, 279287.

Talley, J.E. (1980). Psychological separation-individuation and spiritual reunion. Journal of Psychology and Theology, 8, 97-106.

Taylor, B.C., \& Malony, H.N. (1983). Preferred means of hostility expression among missionaries: An exploratory study. Journal of Psychology and Theology, 11, 218225.

Thomas, D.A. (1984). Hope for binge-eaters and other addicts: A Christian psychoanalytic perspective. Journal of Psychology and Theology, 12, 34-40.

Timpe, R.L. (1983). Ritualizations and ritualisms in religious development: A psychosocial perspective. Journal of Psychology and Theology, 11, 311-317.

Townsend, J.S., II, \& Wichern, F.B. (1984). The development of the spiritual leadership qualities inventory. Journal of Psychology and Theology, 12, 305-313.

Vande Kemp, H. (1982). The tension between psychology and theology: An anthropological solution. Journal of Psychology and Theology, 10, 205-211.

Vanderploeg, R.D. (1981a). Imago Dei as foundational to psychotherapy: Integration versus segregation.Journal of Psychology and Theology, 9, 299-304.

Vanderploeg, R.D. (1981b). Imago Dei, Creation as election: Foundations for psychotherapy. Journal of Psychology and Theology, 9, 209-215.

Virkler, H.A. (1980). The facilitativeness of parish ministers: A descriptive study. Journal of Psychology and Theology, 8, 140-146. 


\section{INTEGRATION MODELS, 1980-1985}

Vitz, P.C., \& Gartner, J. (1984a). Christianity and psychoanalysis, part 1: Jesus as the anti-Oedipus. Journal of Psychology and Theology, 12, 4-14.

Vitz, P.C., \& Gartner, J. (1984b). Christianity and psychoanalysis, part 2: Jesus the transformer of the superego. Journal of Psychology and Theology, 12, 82-90.

Walsh, J.A. (1983). The dream of Joseph: A Jungian interpretation. Journal of Psychology and Theology, 11, 20-27.

Warner, J., \& Carter, J.D. (1984). Loneliness, marital adjustment, and burnout in pastoral and lay persons. Journal of Psychology and Theology, 12, 125-131.

Watson, P.J., Hood, R.W., Jr., Morris, R.J., \& Hall, J.R. (1985). Religiosity, sin and self-esteem. Journal of Psychology and Theology, 13, 116-128.

Westendorp, F. (1982). The interface of psychiatry and religion: A program for career training in psychiatry. Journal of Psychology and Theology, 10, 22-27.

White, F.J. (1983). Some reflections on the separation phenomenon idiosyncratic to the experience of missionaries and their children. Journal of Psychology and Theology, 11, 181-188.

White, S.A. (1984). Imago Dei and object relations theory: Implications for a model of human development. Journal of Psychology and Theology, 12, 286-293.

Wickstrom, D.E., \& Fleck, J.R. (1983). Missionary children: Correlates of self-esteem and dependency. Journal of Psychology and Theology, 11, 226-235.

Worthington, E.L., Jr., \& Gascoyne, S.R. (1985). Preferences of Christians and non-Christians for five
Christian counselors' treatment plans: A partial replication and extension. Journal of Psychology and Theology, 13, 29-41.

Worthington, E.L., Jr., \& Scott, G.G. (1983). Goal selection for counseling with potentially religious clients by professional and student counselors in explicitly Christian or secular settings. Journal of Psychology and Theology, 11, 318-329.

Wright, P.G., (1984). The counseling activities and referral practices of Canadian clergy in British Columbia. Journal of Psychology and Theology, 12, 204-304.

Young, R.G. (1981). Value differentiation as stage transition: An expansion of Kohlbergian moral stages. Journal of Psychology and Theology, 9, 164-174.

\section{AUTHORS}

FOSTER, JAMES D. Address: Department of Psychology, George Fox College, Newberg, Oregon 97132. Title: Associate Professor of Psychology. Degrees: MA, $\mathrm{PhD}$, The Ohio State University. Specializations: Educational and developmental psychology.

HORN, DEBRA A. Address: 1119 NE 136th Street, Vancouver, Washington 98684. Title: Teaching Assistant. Degrees: BA, George Fox College. Specialization: Cognitive-mathematical psychology.

WATSON, STEVE. Address: Department of Psychology, George Fox College, Newberg, Oregon, 97132. Title: Residence Assistant. Specialization: Adolescence. 


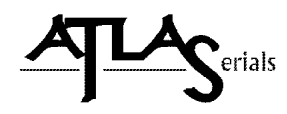

Copyright and Use:

As an ATLAS user, you may print, download, or send articles for individual use according to fair use as defined by U.S. and international copyright law and as otherwise authorized under your respective ATLAS subscriber agreement.

No content may be copied or emailed to multiple sites or publicly posted without the copyright holder(s)' express written permission. Any use, decompiling, reproduction, or distribution of this journal in excess of fair use provisions may be a violation of copyright law.

This journal is made available to you through the ATLAS collection with permission from the copyright holder(s). The copyright holder for an entire issue of a journal typically is the journal owner, who also may own the copyright in each article. However, for certain articles, the author of the article may maintain the copyright in the article. Please contact the copyright holder(s) to request permission to use an article or specific work for any use not covered by the fair use provisions of the copyright laws or covered by your respective ATLAS subscriber agreement. For information regarding the copyright holder(s), please refer to the copyright information in the journal, if available, or contact ATLA to request contact information for the copyright holder(s).

About ATLAS:

The ATLA Serials (ATLAS $®$ ) collection contains electronic versions of previously published religion and theology journals reproduced with permission. The ATLAS collection is owned and managed by the American Theological Library Association (ATLA) and received initial funding from Lilly Endowment Inc.

The design and final form of this electronic document is the property of the American Theological Library Association. 